\title{
Studies of the Family Celastraceae in Jharkhand
}

\author{
Anand Kumar* \\ Central National Herbarium, Botanical Survey of India, P.O. Botanic Garden, Howrah - 711 103, West Bengal, \\ India.
}

*Corresponding Author: Anand Kumar, Central National Herbarium, Botanical Survey of India, P.O. Botanic Garden, Howrah - 711 103, West Bengal, India.

\begin{abstract}
The paper deals with the documentation of species belonging to the family Celastraceae in Jharkhand. A total of 10 species belonging to seven genera are reported from Jharkhand. The genera are Celastrus, Elaeodendron, Euonymus, Gymnosporia, Reissantia, Salacia and Siphonodon. Gymnosporia is the most dominant genus with three species, followed by Reissantia with two species and remaining genera with one species each. Key to the genera and key to the species are also provided here for easy identification of the species found in Jharkhand.
\end{abstract}

Keywords: Celastraceae, Jharkhand, Key.

\section{INTRODUCTION}

The family Celastraceae is characterized by evergreen or deciduous trees, shrubs, lianas, or less frequently herbaceous annuals and perennials which have small, actinomorphic, 4-5-merous bisexual or unisexual flowers with nectary disks occurring on the same or different plants and wide diversity of fruit and aril types (Simmons, 2004). It comprises about 1300 species belonging to 96 genera that are mainly distributed in the tropics and temperate regions of the world (Mabberley, 2017). In India, it is represented by 12 genera and 82 species (Ramamurthy, 2000).

Haines (1910, 1921-1925) and Singh et al.(2001) had contributed to the flora of the erstwhile Bihar while Sarma and Sarkar (2002), Paria and Chattopadhyay (2000, 2005) and Ranjan (2014) have made significant contributions to the Flora of Palamau, Hazaribagh districts and Parasnath Wildlife Sanctuary of Jharkhand, respectively but no one has contributed particularly to the family Celastraceae of the state. Therefore, the present study is the first report to document all species belonging to the family Celastraceae in Jharkhand.

\section{MATERIAL AND MethodS}

\subsection{Study Area}

Jharkhand was formed as a separate state after bifurcation of the erstwhile state of Bihar in the year 2000 and spreads in about $79,716 \mathrm{sq} \mathrm{km}$. The state is rich in forest and mineral reserves. About $23,611 \mathrm{sq} \mathrm{km}$ is under forest cover that constitutes $29.62 \%$ of total geographical area (FSI, 2019). The state possesses many rivers and valleys with undulating tracts, hills and ridges and altitudes ranging from 300 to $900 \mathrm{~m}$. Temperature vary from $4{ }^{\circ} \mathrm{C}$ to $47^{\circ} \mathrm{C}$ and the important rivers are Son, South Koel, Baitarni, Ganga and Damodar. The state has one Tiger Reserve, one Elephant Reserve, one National Park and 11 Wildlife Sanctuaries (Singh and Singh, 2002; WII, 2019).

\subsection{Data Collection and Presentation}

The present work was based on the study of literature (Haines, 1910, 1921-1925; Singh et al., 2001; Sarma and Sarkar, 2002; Paria and Chattopadhyay, 2000, 2005; Ranjan, 2014) and herbarium specimens deposited at CAL and LWG. Key to the genera and key to the species are also provided. Genera and species are arranged alphabetically in the present enumeration. The nomenclature of plants was updated using Plants of the World Online (2019). Each species is provided with accepted name, followed by basionym, if any, synonyms, phenology and distribution. The name of author, book and periodicals cited here are accordance with Brummitt and Powell (1992), Stafleu and Cowan 
(1976-1988), Stafleu and Mennega (1992-2000) and BPH online (http://fmhibd.library.cmu.e du/HIBD-DB/bpho/findrecords.php?-link=Find).

\section{RESULTS AND DISCUSSION}

A total of 10 species belonging to seven genera are reported from Jharkhand. The genera include Celastrus L., Elaeodendron Jacq., Euonymus L., Gymnosporia (Wight \& Arn.) Hook.f, Reissantia N. Hallé, Salacia L. and Siphonodon Griff. Gymnosporia is the most dominant genus with three species, followed by Reissantia with two species and remaining genera with one species each. Life forms include climber with three genera (Celastrus, Reissantia and Salacia) and tree with four genera (Elaeodendron, Euonymus, Gymnosporia and Siphonodon). Elaeodendron glaucum (Rottb.) Pers. commonly known as Khaura or Ratangarur is used for medicinal purpose by local inhabitants of the state as its leaves and barks are used in limb swelling in the state.

Ramamurthy (2000) treated the genus Siphonodon under the family Celastraceae and Ramamurthy and Naithani (2000) treated Hippocrateaceae as distinct family while Singh et al. (2001) treated Celastraceae, Siphonodontaceae and Hippocrateaceae as independent family. But, phylogenetic study supports the taxonomic inclusion of Hippocrateaceae within paraphyletic Celastraceae (Simmons et al., 2001). Jordaan and Van Wyk (1999) reinstated the genus Gymnosporia (Wight \& Arn.) Hook.f. and included all its spiny members which were previously placed under Maytenus Molina sensu lato. Further, the genus Elaeodendron was treated as either distinct genus or synonym of Cassine but phylogenetic study (Islam et al., 2006) supported that both genera should be recognized as distinct genera.

\section{Key to the Genera}

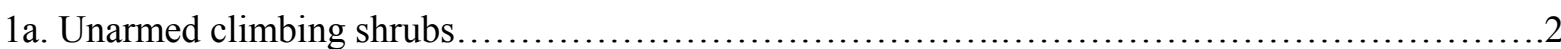

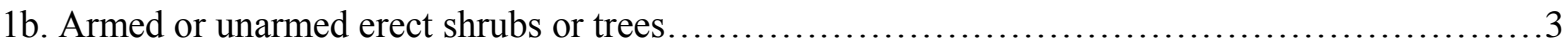

2a. Stamens 5; filaments distinct, often incurved, inserted at or below the margin of the disk; seeds albuminous

1. Celastrus

2b. Stamens 3; filaments connate at the base, recurved, inserted inside the disk; seeds exalbuminous

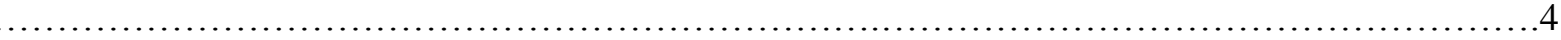

3a. Plants armed 4. Gymnosporia

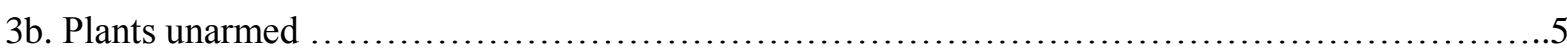

4a. Flowers in panicled cymes; fruits capsular, flattened, dry, dehiscent; seeds winged. 5. Reissantia

4b. Flowers in fascicles; fruits berries, globose, fleshy, indehiscent; seeds not winged. .6. Salacia

5a. Fruits capsule

3. Euonymus

5b. Fruits drupe ...6

6a. Inflorescences dichotomous cymes; ovary 2-loculed. 2. Elaeodendron

6b. Inflorescences not dichotomous cymes; ovary many loculed. ...

7. Siphonodon

\section{Celastrus L.}

(7 species in India and 1 in Jharkhand)

Celastrus paniculatus Willd., Sp. Pl., ed. 4, 1: 1125. 1798; M.A. Lawson in Hook.f., Fl. Brit. India 1: 617. 1875; Haines, Forest Fl. Chota Nagpur: 265. 1910 \& Bot. Bihar Orissa: 188. 1921; Ramam. in N.P. Singh et al., Fl. India 5: 87, f. 18. 2000; Paria \& S.P. Chattop., Fl. Hazaribagh 1: 448. 2000; N.P. Singh et al., Fl. Bihar: 103. 2001; Ranjan, Fl. Parasnth WLS. Jharkhand: 58: 2014. Figure 1a-c

Flowering \& fruiting: April-January.

Distribution: Deoghar, Dumka, East Singhbhum, Giridih, Godda, Gumla, Hazaribagh, Jamtara, Koderma, Palamau, Pakur, Ranchi and Sahibganj. 


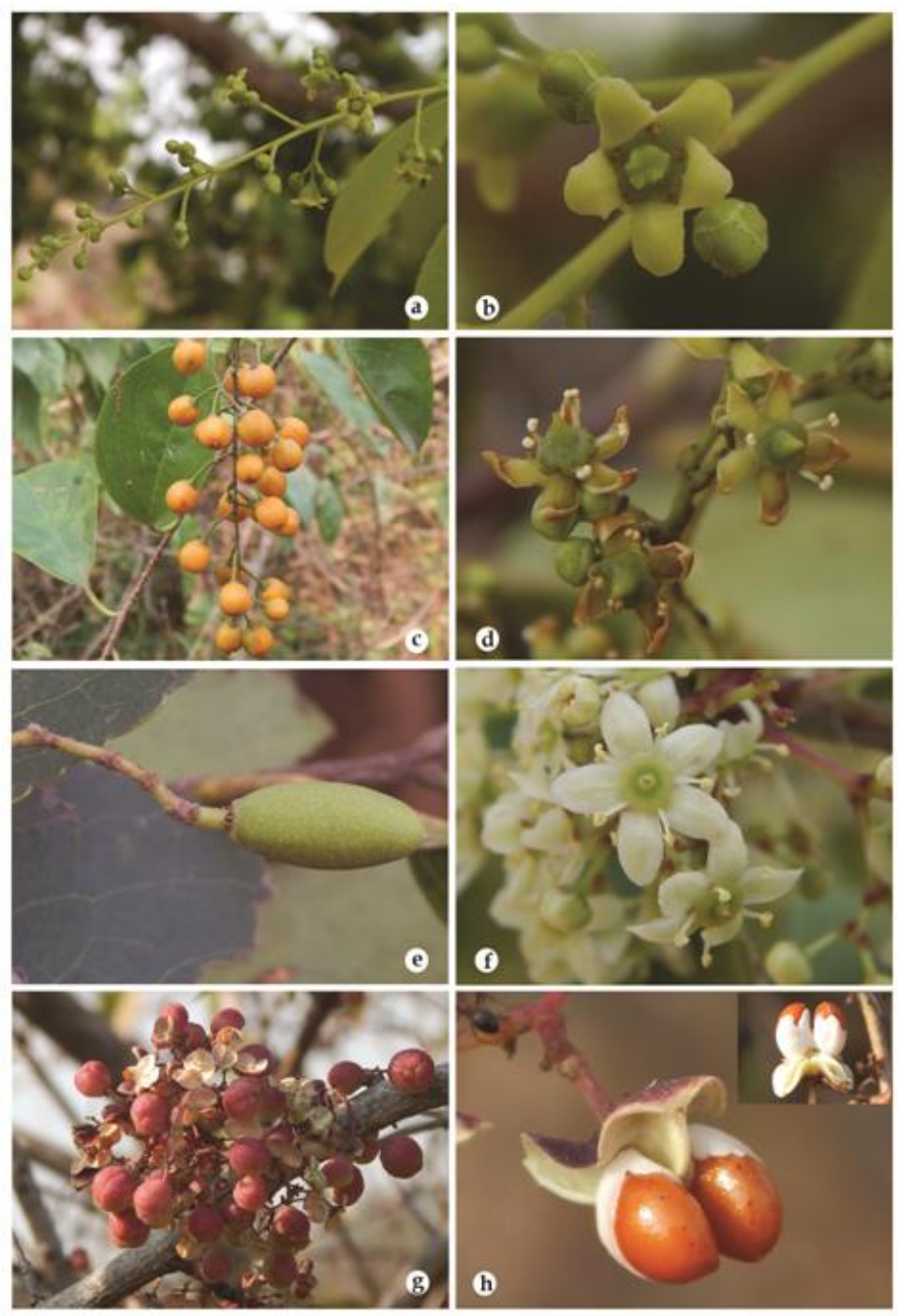

Figure 1. a-c. Celastrus paniculatus Willd: a. inflorescence, b. flower, c. fruits; d-e. Elaeodendron glaucum (Rottb.) Pers.: d. flowers, e. fruit; f-h. Gymnosporia montana (Roth) Benth.: f. flowers, g. fruits, $h$. seeds.

\section{ELAEODENDRON Jacq.}

(4 species in India and 1 in Jharkhand)

Elaeodendron glaucum (Rottb.) Pers., Syn. Pl. 1: 241. 1805; M.A. Lawson in Hook.f., Fl. Brit. India 1: 623. 1875, p.p.; Haines, Forest Fl. Chota Nagpur 266. 1910 \& Bot. Bihar Orissa: 189. 1921. Mangifera glauca Rottb., Nye Saml. Kongel. Danske Vidensk. Selsk. Skr. 2: 534, t. 4, f. 1. 1783. Cassine albens sensu Ramam. in N.P. Singh et al., Fl. India 5: 80, f. 17. 2000 non(Retz.) Kosterm. (1986). Cassine glauca (Rottb.) Kuntze, Revis. Gen. Pl. 1: 114. 1891; Paria \& S.P. Chattop., Fl. Hazaribagh 1: 447. 2000; N.P. Singh et al., Fl. Bihar: 102. 2001; T.K. Sarma \& A.K. Sarkar in N.P. Singh \& P.S.N. Rao, Fl. Palamau: 145. 2002. Figure 1d-e

Flowering \& fruiting: August-December.

Distribution: Deoghar, Godda, Gumla, Hazaribag, Koderma, Pakur, Palamau, Ranchi and Singhbhum.

\section{EUONYMUS L.}

(32 species in India and 1 in Jharkhand)

Euonymus glaber Roxb., Fl. Ind. 2: 403. 1824; M.A. Lawson in Hook.f., Fl. Brit. India 1: 609. 1875; Haines, Bot. Bihar Orissa: 186. 1921; Paria \& S.P. Chattop., Fl. Hazaribagh 1: 449. 2000; Ramam. in N.P. Singh et al., Fl. India 5: 100. 2000; N.P. Singh et al., Fl. Bihar: 103. 2001.

Flowering \& fruiting: April-May.

Distribution: Hazaribagh. 
4. GYMNOSPORIA (Wight \& Arn.) Hook.f.

(18 species in India and 3 in Jharkhand)

\section{Key to the species}

1a. Capsules mainly 2-valved 3. G. senegalensis

1b. Capsules 2 to 3 -valved.

2a. Leaves crenulate; petioles distinct; cymes axillary or on spines, many times divided; capsules 2valved, ocassionally 3 -valved.

2. G. montana

2b. Leaves entire or remotely crenate in distal part; petioles sessile or very short; flowers fascicled, axillary or on spines; capsules 3-valved.

1. G. emarginata

1. Gymnosporia emarginata (Willd.) Thwaites, Enum. Pl. Zeyl.: 409. 1864; M.A. Lawson in Hook.f., Fl. Brit. India 1: 621. 1875; Haines, Bot. Bihar Orissa 187. 1921. Celastrus emarginatus Willd., Sp. Pl. ed. 4, 1: 1128. 1798. Maytenus emarginata (Willd.) Ding Hou in Fl. Males, ser. I, 6: 241. 1962; Ramam. in N.P. Singh et al., Fl. India 5: 120. 2000; N.P. Singh et al., Fl. Bihar: 103. 2001.

Flowering \& fruiting: October - March.

Distribution: Singhbhum.

2. Gymnosporia montana (Roth) Benth., Fl. Austral. 1: 400. 1863; M.A. Lawson in Hook.f., Fl. Brit. India 1: 621. 1875; Haines, Bot. Bihar Orissa: 188. 1921. Celastrus montanus Roth, Syst. Veg. 5: 427. 1819. Figure 1f-h

Flowering \& fruiting: March-Januray.

Distribution: Hazaribagh.

3. Gymnosporia senegalensis (Lam.) Loes., Bot. Jahrb. Syst. 17: 541 1893. Celastrus senegalensis Lam., Encycl. 1: 661. 1785. Maytenus senegalensis (Lam.) Exell., Bot. Soc. Brot., ser. 2, 26: 223. 1952; Ramam. in N.P. Singh et al., Fl. India 5: 126. 2000; N.P. Singh et al., Fl. Bihar: 104. 2001; Ranjan, Fl. Parasnth WLS. Jharkhand: 60: 2014.

Flowering \& fruiting: October-December.

Distribution: Giridih and Hazaribagh.

5. REISSANTIA N. Hallé

(3 species in India and 2 in Jharkhand)

Key to the species

1a. Leaves membranous; stipules subulate 1. R. arborea

1b. Leaves chartaceous; stipules 3-angled, 3-lobed 2. R. indica

1. Reissantia arborea (Roxb.) H. Hara in J. Jap. Bot. 40: 327. 1965; Ramam. \& B.D. Naithani in N.P. Singh et al., Fl. India 5: 147. 2000; N.P. Singh et al., Fl. Bihar: 104. 2001. Hippocratea arborea Roxb., Pl. Coromandel 3: 3. t. 205. 1811; M.A. Lawson in Hook.f., Fl. Brit. India 1: 625. 1875.

Flowering \& fruiting: November-August.

Distribution: Bihar (Ramamurthy \& Naithani, 2000).

2. Reissantia indica (Willd.) N. Hallé, Mém. Inst. Franç. Afrique Noire 64: 85. 1962. Ramam. \& B.D. Naithani in N.P. Singh et.al, Fl. India 5: 149. 2000; N.P. Singh et al., Fl. Bihar: 105. 2001. Hippocratea indica Willd., Sp. Pl., ed. 4, 1: 193. 1797; M.A. Lawson in Hook.f, Fl. Brit. India 1: 624. 1875.

Flowering \& fruiting: March-April.

Distribution: Gumla.

6. SALACIA L.

(22 species in India and 1 in Jharkhand)

International Journal of Advanced Research in Botany (IJARB) 
Salacia chinensis L., Mant. Pl.: 293. 1771. Ramam. \& B.D. Naithani in N.P. Singh et al., Fl. India 5: 152. 2000; N.P. Singh et al., Fl. Bihar: 105. 2001. Tontelea prinoides Willd., Neue Schriften Ges. Naturf. Freunde Berlin 4: 184. 1803. S. prinoides (Willd.) DC., Prodr. 1: 571. 1824; M.A. Lawson in Hook.f., Fl. Brit. India 1: 626. 1875.

Flowering \& fruiting: January-April.

Distribution: Bihar (Ramamurthy \& Naithani, 2000).

\section{SIPHONODON Griff.}

(1 species in India and Jharkhand)

Siphonodon celastrineus Griff. in Calcutta J. Nat. Hist. 4: 247. t. 14. 1844; M.A. Lawson in Hook.f., Fl. Brit. India 1: 629. 1875; Haines, Forest. Fl. Chota Nagpur: 267. 1910 \& Bot. Bihar. Orissa: 190. 1921; Ramam. in N.P. Singh et al., Fl. India 5: 137. 2000; Paria \& S.P. Chattop., Fl. Hazaribagh 1: 449. 2000; N.P. Singh et al., Fl. Bihar: 104. 2001.

Flowering \& fruiting: April-June.

Distribution: Daltonganj, Hazaribagh and Sahibganj.

\section{ACKNOWLEDGEMENT}

The author is thankful to Dr. A.A. Mao, Director, Botanical Survey of India, Kolkata and Dr. V.P. Prasad, Head of Office, Central National Herbarium, Howrah for the facilities. I am also grateful to the Director, CSIR-National Botanical Research Institute for permission to access the herbarium.

\section{REFERENCES}

[1] Anderson, T. (1863). On the flora of Bihar and the mountains of Parasnath with a list of species collected by Messrs Hooker, Edgeworth, Thomson and Anderson. J. Asiat. Soc. Bengal 32: 189-218.

[2] Brummitt, R.K. and Powell, C.E. (eds.) (1992). Authors of Plant Names. Royal Botanic Gardens, Kew.

[3] FSI (2019). India State of Forest Report, vol. 2. Forest Survey of India, Dehradun, India.

[4] Haines, H.H. (1910). A Forest flora of Chotanagpur including Gangpur and the Santal Parganahs - A description of all the indigenous trees, shrubs and climbers, the principal economic herbs, and most common cultivated trees and shrubs (with introduction and glossary). Superintendent Govt. Printing, Calcutta.

[5] Haines, H.H. (1921-1925). The Botany of Bihar and Orissa: An account of all the known indigenous plants of the province and of the most important or most commonly cultivated exotic ones with maps and introduction. 6 Parts. Adlard \& Son, London.

[6] Hooker, J.D. (1848). Observations made when following Grand Trunk Road across the hills of Upper Bengal, Parasnath, etc. in the Soan Valley and on the Kumaon branch of the Vindhya hills. J. Asiat. Soc. Bengal 17: 355-411.

[7] Islam, M.B., Simmons, M.P. and Archer, R.H. (2006). Phylogeny of the Elaeodendron Group (Celastraceae) Inferred from Morphological Characters and Nuclear and Plastid Genes. Syst. Bot. 31: 512-524.

[8] Jordaan, M. and Van Wyk, A.E. (1999). Systematic studies in subfamily Celastroideae (Celastraceae) in southern Africa: reinstatement of the genus Gymnosporia. S. African J. Bot. 65: 177-181.

[9] Mabberley, D.J. (2017). Mabberley's plant-book: A portable dictionary of plants, their classification and uses. $4^{\text {th }}$ Edition. Cambridge University Press, Cambridge.

[10] Paria, N.D. and Chattopadhyay, S.P. (2000, 2005). Flora of Hazaribagh District, Bihar, vols. 1-2. Botanical Survey of India, Calcutta.

[11] Plants of the World Online (2019). Plants of the World Online. Downloaded from http://www.plantsoftheworldonline.org/ on 16 December 2019.

[12] Ramamurthy, K. and Naithani, B.D. (2000). Hippocrateaceae. In: Singh, N.P., Vohra, J.N., Hajra, P.K. and Singh, D.K. (eds.), Flora of India, vol. 5. Botanical Survey of India, Calcutta, pp. 138-162.

[13] Ramamurthy, K. (2000). Celastraceae. In: Singh, N.P., Vohra, J.N., Hajra, P.K. and Singh, D.K. (eds.), Flora of India, vol. 5. Botanical Survey of India, Calcutta, pp. 75-137.

[14] Ranjan, V. (2014). Flora of the Parasnath Wildlife Sanctuary, Jharkhand. Bishen Singh Mahendra Pal Singh, Dehradun.

[15] Sarma, T.K. and Sarkar, A.K. (2002). In: Singh, N.P. and Rao, P.S.N. (eds.), Flora of Palamau District, Jharkhand. Botanical Survey of India, Calcutta. 
[16] Simmons, M.P. (2004). Celastraceae. In: Kubitzki, K. (Ed.), the Families and Genera of Flowering Plants, vol. 6. Springer, Berlin, pp. 29-64.

[17] Simmons, M.P., Clevinger, C.C., Savolainen, V., Archer, R.H., Mathews, S. and Doyle, J.J. (2001). Phylogeny of the Celastraceae inferred from phytochrome B and morphology. Amer. J. Bot. 88: 313-325. https://doi.org/10.2307/2657021

[18] Singh, N.P. and Singh, D.K. (2002). Protected Area Network. In: Singh NP \& Singh KP (eds) Floristic Diversity and Conservation Strategies in India (In-situ and Ex-situ Conservation). Vol. 5. Botanical Survey of India, Kolkata, pp. 2341-2412.

[19] Singh, N.P., Mudgal, V., Khanna, K.K., Srivastava, S.C., Sahoo, A.K., Bandapadhyay, S., Aziz, N., Das, M., Bhattacharya, R.P. and Hajra, P.K. (2001). Flora of Bihar. Analysis. Botanical Survey of India, Calcutta.

[20] Stafleu, F.A. and Cowan, R.S. (1976-1988). Taxonomic Literature. ed. 2. Regnum Veg. Vols. 94, 98, 105, 110, 112, 115, 116. A.R.G. Gantner Verlag K.G., Ruggell.

[21] Stafleu, F.A. and Mennega, E.A. (1992-2000). Taxonomic Literature (Suppl.). Regnum Veg. Vols. 125, 130, 132, 134, 135, 137. A.R.G. Gantner Verlag K.G., Ruggell.

[22] WII (2019) Protected Areas of India. Downloaded from http://www.wiienvis.nic.In/Database /Protected_Area_854.aspx on 16 December 2019.

Citation: Anand Kumar, "Studies of the Family Celastraceae in Jharkhand" International Journal of Advanced Research in Botany, vol.6, no.1, p.9-14,2020. http://dx.doi.org/10.20431/2454-9444.06001002

Copyright: (C) 2020 Authors. This is an open-access article distributed under the terms of the Creative Commons Attribution License, which permits unrestricted use, distribution, and reproduction in any medium, provided the original author and source are credited. 